\title{
Corporate Social Responsibility, Profitabilitas, Capital Intensity dan Penghindaran Pajak
}

\author{
Putu Shandya Maharani ${ }^{1}$ \\ Fakultas Ekonomi dan Bisnis \\ Universitas Udayana, Indonesia
}

\author{
Ni Ketut Lely Aryani Merkusiwati2 \\ Fakultas Ekonomi dan Bisnis \\ Universitas Udayana, Indonesia
}

Surel : shandyamaharani25@gmail.com

\section{ABSTRAK}

Penelitian ini dilakukan untuk mendapat bukti empiris mengenai pengaruh corporate social responsibility, profitabilitas, dan capital intensity pada perusahaan pertambangan yang terdaftar di Bursa Efek Indonesia tahun 2013-2017. Jumlah sampel yang diambil sebanyak 9 perusahaan dengan 35 amatan memenuhi kriteria penentuan sampel. Sampel ditentukan dengan menggunakan metode purposive sampling. Teknik analisis yang digunakan adalah analisis linier berganda. Berdasarkan hasil analisis ditemukan bahwa CSR dan Profitabilitas berpengaruh negatif terhadap penghindaran pajak, hal ini berarti semakin tinggi CSR dan profitabilitas semakin rendah tingkat pengindaran pajak. Sementara capital intensity berpengaruh positif terhadap penghindaran pajak, hal ini berarti bahwa semakin tinggi capital intensity, semakin tinggi tingkat penghindaran pajak.

\section{Kata Kunci: Penghindaran Pajak; Corporate Social Responsibility; Profitabilitas; Capital Intensity.}

The Effect of Corporate Social Responsibility, Profitability, and Capital Intensity on Tax Avoidance

\begin{abstract}
This study aims to obtain empirical evidence regarding the effect of corporate social responsibility, profitability, and capital intensity on tax avoidance of mining companies listed on Indonesia Stock Exchange in 2013-2017. The method of determining the sample is using purposive sample. The samples were taken from 9 companies with 35 observations. The samples were determining by purposive sampling method. Analysis technique was using multiple regression. Based on the result of research, CSR and profitability have negative effect on tax avoidance. This means the higher CSR and profitability, the lower level of tax avoidance. Meanwhile, capital intensity has positive effect on tax avoidance. This means the higher capital intensity, the higher level of tax avoidance.

Keywords: Tax Avoidance; Corporate Social Responsibility; Profitability; Capital Inensity.
\end{abstract}

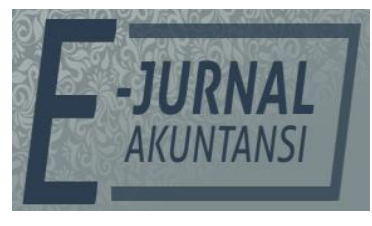

e-ISSN 2302-8556

Vol. 31 No. 6

Denpasar, Juni 2021

Hal. 1481-1493

DOI:

10.24843/EJA.2021.v31.i06.p10

PENGUTIPAN:

Maharani, P.S., \&

Merkusiwati, N.K.L.A. (2021).

Corporate Social Responsibility,

Profitabilitas, Capital Intensity dan Penghindaran Pajak. EJurnal Akuntansi, 31(6), 1481-

1493

RIWAYAT ARTIKEL:

Artikel Masuk:

3 Desember 2019

Artikel Diterima:

26 Februari 2021

Artikel dapat diakses : https://ojs.unud.ac.id/index.php/Akuntansi/index 


\section{PENDAHULUAN}

Pajak merupakan sumber pendapatan negara, kesuksesan suatu negara juga sangat dipengaruhi oleh penghasilan pajaknya (Merkusiwati \& Damayanti, 2018). Perusahaan yang merupakan wajib pajak, memandang pajak sebagai beban (Anouar, 2017). Menurut Zhu, et. al. (2019) seluruh kegiatan yang terkait dengan penghindaran pajak perusahaan, semata-mata untuk meningkatkan keuntungan dan efisiensi pajak perusahaan. Pembayaran pajak yang dilakukan oleh perusahaan dapat dikurangi dengan cara memanfaatkan celah-celah dalam undang-undang perpajakan (Rizki \& Fuadi, 2019). Hal tersebut menyebabkan perusahaan dapat melakukan penghindaran pajak secara legal, namun pemerintah tetap menginginkan pungutan pajak yang ditujukan kepada pengusaha maksimal. Gambaran realisasi dan penerimaan pajak lima tahun terakhir dapat dilihat pada Tabel 1, berikut.

Tabel 1. Realisasi dan Target Penerimaan Pajak Tahun 2013-2017

\begin{tabular}{llll}
\hline Tahun & Target & Realisasi & Presentase \\
\hline 2013 & 995,2 triliun & 921,3 trilun & 92,6 \\
2014 & $1.072,4$ triliun & 981,8 triliun & 91,6 \\
2015 & $1.294,2$ triliun & $1.060,83$ triliun & 82 \\
2016 & $1.355,2$ triliun & $1.105,81$ triliun & 81,6 \\
2017 & $1.285,6$ triliun & $1.151,13$ triliun & 89,7 \\
\hline
\end{tabular}

Sumber: Kementerian Keuangan Republik Indonesia, 2018

Laporan kinerja Kementerian Keuangan dari tahun 2013 hingga tahun 2017 menunjukkan bahwa target dan realisasi penerimaan pajak di Indonesia selalu mengalami kenaikan, hal ini menggambarkan potensi pajak di Indonesia cukup besar. Walaupun terjadi kenaikan penerimaan pajak dari tahun ke tahun, namun pada kenyataannya realisasi penerimaan pajak mengalami penurunan dari yang telah ditargetkan. Berdasarkan Tabel 1, terjadi penurunan realisasi penerimaan pajak yang cukup besar di tahun 2015 yaitu sebesar 9,6 persen.

Indonesia memiliki kekayaan alam yang sangat melimpah, daerah-daerah subur seperti Kalimantan dan Papua memiliki banyak tambang-tambang raksasa yang menyebabkan tingginya nilai ekonomi yang dihasilkan oleh industri tambang. Tingginya nilai ekonomi yang dihasilkan oleh tambang tersebut tidak sebanding dengan kontribusi pajaknya. Minimimnya kontribusi pajak yang dihasilkan dapat dilihat dari rasio pendapatan pajak terhadap Produk Domestik Bruto (PDB) atau tax ratio pertambangan di Indonesia. Tahun 2011, tax ratio pertambangan Indonesia sebesar 12,9 persen, sementara hingga tahun 2016 mengalami penurunan ke angka 3,8 persen. Organization for Economic Co-operation and Development (OECD) menilai salah satu penyebab rendahnya tax ratio di Indonesia adalah penghindaran pajak yang dilakukan oleh wajib pajak. Transfer pricing, memanfaatkan insentif pajak (tax holiday) dan mengganti nama perusahaan merupakan tiga modus yang biasanya digunakan perusahaan untuk melakukan penghindaran pajak (Cahyono, et. al., 2016).

Perusahaan merasa berat untuk memenuhi kewajiban sebagai wajib pajak karena perusahaan tidak mendapatkan manfaat langsung dari pembayaran pajak (Dharma \& Noviari, 2017). Perusahaan yang melakukan praktik penghindaran pajak dapat diasumsikan bahwa perusahaan tersebut berusaha untuk memaksimalkan laba yang diperolehnya (Goerke, 2018). Penelitian ini 
menggunakan Effective Tax Rate (ETR) sebagai pengukuran penghindaran pajak. Peneliti Henry \& Sansing (2018) juga Kim \& Im, (2017) mengemukakan bahwa ETR menggambarkan beban pajak perusahaan dan dampak pajak pada bisnis.

Tujuan utama praktik penghindaran pajak yang dilakukan perusahaan ialah mengurangi beban pajak yang dibayarkan oleh perusahaan (Kasim \& Saad, 2019). Perusahaan disebut tidak mempunyai tanggung jawab sosial jika perusahaantersebut memiliki kecenderungan untuk melakukan praktik penghindaran perpajakan (Hidayati \& Fidiana, 2017). Strategi perusahaan untuk melakukan penghindaran pajak memiliki risiko bagi perusahaan, ialah denda dan buruknya reputasi perusahaan di mata publik (McClure, et. al., 2018). Tanggung jawab sosial suatu perusahaan atau Corporate Social Responsibility (CSR) menjadi suatu hal yang semakin penting dalam dunia bisnis. Para pemangku kepentingan menuntut perusahaan melakukan tindakan transparansi yang lebih besar dalam melaporkan kegiatan CSR (Atikah, et. al., 2018). Menurut teori legitimasi, perusahaan berusaha melegitimasi masyarakat bahwa perusahaan tersebut telah melakukan kegiatan sesuai dengan batas dan norma-norma juga perusahaan akan berusaha menampilkan citra terbaik mereka, salah satunya dengan melakukan pembayaran pajak (Lin, et. al., 2017). CSR merupakan faktor kunci kesuksesan dan kelangsungan hidup perusahaan (Lanis \& Richardson, 2012).

Penelitian ini tentang hubungan CSR dengan penghindaran pajak, yang mana telah terlebih dulu diteliti oleh beberapa peneliti, diantaranya yaitu Lanis \& Richardson (2012) mengungkapkan bahwa semakin tinggi pengungkapan tanggung jawab sosial suatu perusahaan maka semakin rendah tingkat penghindaran pajak dari perusahaan tersebut. Sementara, Preuss, (2010) dan Sikka (2010) berpendapat bahwa beberapa perusahaan yang mengklaim melakukan CSR tetap melakukan penghindaran pajak.

Profitabilitas menjadi salah satu faktor yang menentukan seberapa tingkat pembayaran pajak yang dibayarkan oleh perusahaan. Profitabilitas atau kemampuan memperoleh laba ialah suatu ukuran dalam persentase yang digunakan untuk sejauh mana perusahaan mampu untuk menghasilkan laba pada tingkat yang diterima (Dicky \& Saputra, 2017). Profitabilitas terdiri dari beberapa rasio salah satunya yaitu Return on Assets (ROA). ROA ialah cerminan dari kinerja perusahaan dalam menghasilkan laba dari pengelolalaan aktiva. Menurut teori keagenan, manajemen diberikan wewenang oleh stakeholder sebagai agen dalam mengelola laba perusahaan. Semakin tinggi ROA perusahaan, maka dapat dikatakan kinerja perusahan tersebut baik. Sebelumnya, terdapat beberapa penelitian mengenai pengaruh profitabilitas terhadap penghindaran pajak. Penelitian terkait profitabilitas dengan ROA sebagai indikator pengukuran yaitu Maharani \& Suardana (2014), dan Hazır (2019). Penelitian terkait juga dilakukan oleh penelitian Darmawan \& Sukartha (2014), Fatharani, (2012), dan Nugroho (2011) yang menunjukkan ROA berpengaruh positif terhadap penghindaran pajak.

Setiap tahun aset tetap akan mengalami penyusutan yang mana akan menjadi biaya penyusutan dalam laporan keuangan perusahaan. Tentunya biaya penyusutan tersebut dapat mengurangi penghasilan dalam perhitungan pajak perusahaan. Oleh karena itu, dapat disimpulkan bahwa semakin kecil biaya penyusutan maka semakin besar tingkat pajak yang harus dibayarkan 
perusahaan. Sehingga, perusahaan dengan tingkat rasio intensitas modal yang besar menunjukkan bahwa tingkat pajak efektif perusahaan tersebut rendah. Sebelumnya, telah dilakukan berbagai penelitian terkait dengan pengaruh capital intensity terhadap penghindaran pajak. Menurut Putra \& Merkusiwati (2016) capital intensity berpengaruh positif terhadap penghindaran pajak. Sedangkan, menurut Muzakki \& Darsono (2015) juga Dharma \& Ardiana (2016) menyatakan bahwa capital intensity berpengaruh negatif terhadap penghindaran pajak.

Pemenuhan kewajiban yang dilakukan dengan membayar pajak secara patuh dan penuh dengan kesadaran dapat meningkatkan hubungan perusahaan dan pemerintah kearah yang lebih baik. Akibat aktivitas penghindaran pajak yang dilakukan oleh perusahaan, maka perusahaan tersebut memiliki lebih berisiko karena berpengaruh buruk pada citra perusahaan (Zeng, 2018). Hal ini sejalan dengan teori stakeholder, aktivitas yang dilakukan oleh perusahaan tidak hanya memengaruhi kepentingan perusahaan itu sendiri, namun juga memengaruhi pihak-pihak yang berkepentingan atau stakeholder yang terkena dampak aktivitas perusahaan tersebut (Ghozali \& Chariri, 2007).

Kegiatan CSR ialah bentuk dari tanggung jawab perusahaan terhadap pemangku kepentingan dengan mengkomunikasikan dampak sosial dan lingkungan perusahaan. Perusahaan yang memenuhi kewajibannya sebagai wajib pajak disebut sebagai perusahaan yang taat akan tanggung jawabnya secara sosial. Menurut penelitian terdahulu yaitu Muzakki \& Darsono (2015) dan Dharma \& Noviari (2017) menemukan bahwa CSR berpengaruh negatif terhadap penghindaran pajak.

Teori dan penelitian terdahulu mengemukakan bahwa semakin rendah tingkat penghindaran pajak perusahaan maka semakin tinggi tanggun jawab sosial suatu perusahaan. Perusahaan yang taat akan kewajiban pajaknya akan memenuhi tanggung jawab sosialnya. Oleh karena itu, dalam penelitian ini terbentuklah hipotesis sebagai berikut.

$\mathrm{H}_{1}$ : Corporate Social Responsibility (CSR) berpengaruh negatif terhadap Penghindaran Pajak.

Profitabilitas merupakan kemampuan perusahaan untuk memperoleh keuntungan dari kegiatan yang dilakukan perusahaan. Semakin besar tingkat profitabilitas yang dimiliki suatu perusahaan, maka semakin besar pula beban pajak yang harus dibayarkan oleh perusahaan kepada pemerintah. Perusahaan menyiapkan perencanaan pajak sedemikian rupa sehingga perusahaan bisa meminimalkan pembayaran pajaknya (Bird \& Davis-Nozemack, 2018). Teori keagenan menyatakan bahwa manajemen yang berwenang agen memiliki tanggung jawab untuk mengelola laba perusahaan, sehingga manajemen dapat melakukan mengatur tingkat kewajiban pajak yang harus dibayarkan. Dan menurut teori akuntansi positif, metode akuntansi yang dipilih perusahaan dapat digunakan untuk mengatur tingkat laba yang dimiliki perusahaan.

Menurut penelitian terdahulu yaitu, Putri \& Gunawan (2017) dan Saputra, et. al., (2015) menyatakan bahwa profitabilitas memengaruhi penghindaran pajak secara positif. Berdasarkan teori dan penelitian terdahulu dapat ditarik kesimpulan bahwa semakin tinggi perusahaan tersebut memeroleh laba, sehingga ETR perusahaan semakin rendah maka semakin tinggi pula penghindaran pajak 
yang dilakukan oleh perusahaan. Hipotesis yang terbentuk dalam penelitian ini sebagai berikut.

$\mathrm{H}_{2}$ : Profitabilitas berpengaruh positif terhadap Penghindaran Pajak.

Teori agensi menyatakan bahwa adanya kontrak antara pihak pemberi kewenangan kepada pihak yang mendapat wewenang atau manajemen untuk melakukan sesuatu yang berkaitan dengan kepentingan pihak yang berwenang, kepentingan manajemen adalah untuk mendapat kompensasi yang diinginkan dengan cara meningkatkan kinerja perusahaan, sehingga manajemen dapat memanfaatkan penyusutan aset tetap untuk menekan beban pajak perusahaan. Salah satu permasalahan yang fokus dibahas dalam teori agensi yaitu perbedaan kepentigan yang dimiliki oleh agen dan principal (Amidu \& Coffie, 2019). Rodriguez \& Arias (2012) menjelaskan bahwa aset tetap yang dimiliki perusahaan memungkinkan perusahaan untuk memotong pajak akibat depresiasi dari aktiva tetap setiap tahunnya. Aset tetap akan mengalami penyusutan yang akan menjadi biaya penyusutan dalam laporan keuangan perusahaan (Novitasari, et. al., 2017). Teori akuntansi positif yang memberikan pilihan kebijakan akuntansi dan memanfaatkan kebijakan akuntansi yang ada untuk meningkatkan labanya, yang mana dalam investasi pada aset, perusahaan dapat memilih metode depresiasi yang dipandang dapat meningkatkan laba perusahaan.

Menurut penelitian terdahulu yaitu, Putri \& Lautania (2016) dan Dharma \& Noviari (2017) menyatakan bahwa capital intensity memengaruhi penghindaran pajak secara positif. Berdasarkan teori dan penelitian terdahulu dapat dinyatakan bahwa semakin tinggi intensitas asset tetap suatu perusahaan, maka semakin tinggi pula praktik penghindaran pajak yang dilakukan oleh perusahaan. Maka, hipotesis yang digunakan dalam penelitian ini sebagai berikut.

$\mathrm{H}_{3}$ : Capital Intensity berpengaruh positif terhadap Penghindaran Pajak.

\section{METODE PENELITIAN}

Penelitian dilaksanakan dengan mengambil data dari Bursa Efek Indonesia (BEI) dengan mengakses situs resmi BEI yaitu www.idx.co.id. BEI dipilih karena cukup representatif untuk mengakses data. Objek penelitian yaitu perusahaan sektor pertambangan yang terdaftar (listing) di Bursa Efek Indonesia pada periode 20132017.

Populasi dalam penelitian ini adalah seluruh perusahaan di sektor pertambangan yang terdaftar di Bursa Efek Indonesia (BEI) periode 2013-2017 serta mempublikasikan laporan kegiatan Corporate Social Responsibility yang telah dilaksanakan. Pada penelitian ini menggunakan perusahaan pertambangan yang terdaftar di Bursa Efek Indonesia (BEI) periode 2013-2017. Pemilihan sampel dilakukan sesuai dengan kriteria yang ditentukan agar sesuai dengan tujuan penelitian.

Penelitian ini dilakukan dengan analisis regresi berganda atau multiple regression analysis. Sebelum melakukan pengujian hipotesis terlebih dahulu dilakukan pengujian atas data, yaitu uji asumsi klasik. Adapun model regresi dalam penelitian ini adalah sebagai berikut.

$Y=\alpha+\beta_{1} X_{1}+\beta_{2} X_{2}+\beta_{3} X_{3}+\varepsilon$

Keterangan:

Y : Penghindaran pajak diukur dengan proksi ETR. 


$\begin{array}{ll}\mathrm{a} & : \text { Konstanta. } \\ \beta & : \text { Koefisien Variabel. } \\ \mathrm{X}_{1} & : \text { Corporate Social Responsibility } \\ \mathrm{X}_{2} & : \text { Profitabilitas } \\ \mathrm{X}_{3} & : \text { Capital Intensity } \\ \varepsilon & : \text { Error (Kesalahan pengganggu) }\end{array}$

\section{HASIL DAN PEMBAHASAN}

Penelitan ini menggunakan teknik analisis regresi linear berganda. Analisis ini dilakukan untuk mengetahui ada tidaknya pengaruh antara variabel bebas yaitu Corporate Social Responsibility $\left(\mathrm{X}_{1}\right)$, Profitabilitas (X2) dan Capital Intensity (X3) pada variabel terikat yaitu Penghindaran Pajak (Y) perusahaan pertambangan yang diproksikan dengan Effective Tax Rate (ETR). Hasil analisis regresi linear berganda dapat dilihat pada Tabel 2.

Tabel 2. Rekapitulasi Hasil Analisis Regresi Linear Berganda

\begin{tabular}{|c|c|c|c|c|c|}
\hline \multirow[t]{2}{*}{ Model } & \multicolumn{2}{|c|}{$\begin{array}{l}\text { Unstandardized } \\
\text { Coefficients }\end{array}$} & \multirow{2}{*}{$\begin{array}{l}\text { Standardized } \\
\text { Coefficients } \\
\text { Beta }\end{array}$} & \multirow[t]{2}{*}{$\mathrm{t}$} & \multirow[t]{2}{*}{ Sig. } \\
\hline & $\mathrm{B}$ & Std. Error & & & \\
\hline (Constants) & 1,005 & 0,068 & & 4,209 & 0,000 \\
\hline CSR & $-0,464$ & 0,348 & $-0,220$ & 1,335 & 0,005 \\
\hline Profitabilitas & $-0,167$ & 0,137 & $-0,201$ & 1,216 & 0,009 \\
\hline Capital Intensity & 0,283 & 0,161 & 0,239 & 1,716 & 0,017 \\
\hline
\end{tabular}

Sumber: Data Penelitian, 2019

Berdasarkan Tabel 2, maka dihasilkan persamaan regresi sebagai berikut.

$\mathrm{Y}=1,005+-0,464 \mathrm{X} 1+-0,167 \mathrm{X} 2+0,283 \mathrm{X} 3$

Nilai konstanta (a) sebesar 1,005 memiliki arti bahwa apabila nilai pengungkapan CSR (X1), Profitabilitas (X2), dan Capital Intensity (X3) adalah 0, maka nilai penghindaran pajak $(\mathrm{Y})$ adalah sebesar 1,005. Variabel Corporate Social Responsibility (X1) memiliki nilai sebesar -0,464. Berdasarkan hasil tersebut CSR (X1) bernilai negatif, yang artinya apabila CSR meningkat dengan anggapan variabel bebas lainnya konstan akan menurunkan penghindaran pajak sebesar 0,464. Variabel Profitabilitas (X2) memiliki nilai sebesar -0,167. Berdasarkan hasil tersebut Profitabilitas (X2) bernilai negatif, yang artinya apabila Profitabilitas meningkat dengan anggapan variabel bebas lainnya konstan akan menurunkan penghindaran pajak sebesar -0,163. Variabel Capital Intensity (X3) memiliki nilai sebesar 0,283. Berdasarkan hasil tersebut Capital Intensity (X3) bernilai positif, yang artinya apabila Capital Intensity meningkat dengan anggapan variabel bebas lainnya konstan akan meningkatkan penghindaran pajak sebesar 0,283.

Pada penelitian ini koefisien determinasi dilihat melalui nilai $\mathrm{R}^{2}$. Adapun nilai dari $\mathrm{R}^{2}$ pada penelitian ini disajikan pada Tabel 3.

Tabel 3. Hasil Uji Koefisien Determinasi $\left(\mathbf{R}^{2}\right)$

\begin{tabular}{lllll}
\hline Model & $R$ & $R^{2}$ & Adjusted $R^{2}$ & $\begin{array}{l}\text { Std. Error of } \\
\text { the Estimate }\end{array}$ \\
\hline 1 & $0,497^{a}$ & 0,243 & 0,221 & 0,65764 \\
\hline
\end{tabular}

Sumber: Data Penelitian, 2019

Berdasarkan Tabel 3, nilai $\mathrm{R}^{2}$ sebesar 0,243 yang berarti bahwa 24,3 persen variasi penghindaran pajak dapa dijelaskan oleh variabel CSR, profitabilitas, dan 
capital intensity. Sisanya sebesar 75,7 persen dipengaruhi oleh variabel lain diluar model yang digunakan dalam penelitian ini.

Uji statistik F dilakukan untuk menguji apakah model yang digunakan dalam penelitian ini layak atau tidak untuk digunakan sebagai alat analisis dalam menguji pengaruh variabel independen pada variabel dependennya. Hasil yang diperoleh dari pengujian kelayakan model dalam penelitian ini disajikan pada Tabel 4.

Tabel 4. Hasil Uji Kelayakan Model (Uji F)

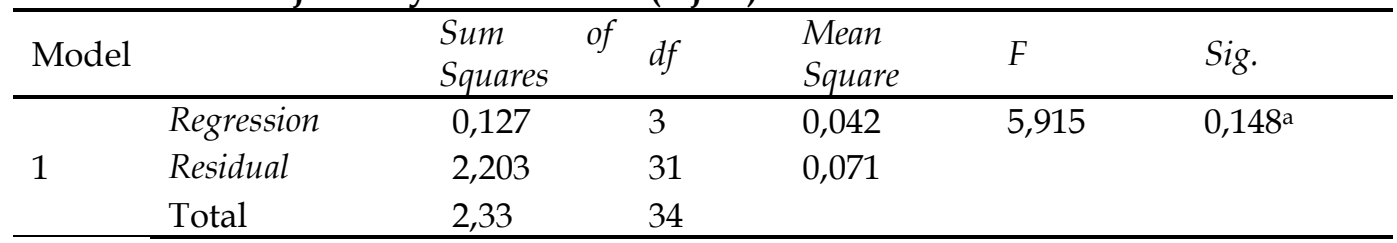

Sumber: Data Penelitian, 2019

Berdasarkan Tabel 4, dapat dilihat bahwa nilai $\mathrm{F}$ hitung adalah sebesar 5,915. Sedangkan nilai $\mathrm{F}$ tabel sebesar 2,92. Untuk mengetahui nilai $\mathrm{F}$ tabel yaitu dengan cara $(\mathrm{k}, \mathrm{n}-\mathrm{k})=(3,35-3)=(3,32)$. Berdasarkan hasil tersebut maka dapat diperoleh $\mathrm{F}$ hitung $>\mathrm{F}$ tabel, sehingga dapat dinyatakan bahwa seluruh variabel independen layak untuk menguji variabel dependen.

Uji statistik $t$ dilakukan untuk mengetahui seberapa jauh pengaruh satu variabel independen secara individual menerangkan variasi variabel dependen. Uji t dilakukan dengan membandingkan hasil nilai signifikansi dengan $\alpha=0,05$. Hasil statistik uji t disajikan dalam Tabel 5, sebagai berikut.

\section{Tabel 5. Hasil Uji Statistik $t$}

\begin{tabular}{|c|c|c|c|c|c|}
\hline \multirow{2}{*}{ Model } & \multicolumn{2}{|c|}{$\begin{array}{l}\text { Unstandardized } \\
\text { Coefficients }\end{array}$} & \multirow{2}{*}{$\begin{array}{l}\text { Standardized } \\
\text { Coefficients } \\
\text { Beta }\end{array}$} & \multirow{2}{*}{$\mathrm{T}$} & \multirow{2}{*}{ Sig. } \\
\hline & B & $\begin{array}{l}\text { Std. } \\
\text { Error }\end{array}$ & & & \\
\hline (Constants) & 1,077 & 0,277 & & 3,888 & 0,030 \\
\hline CSR & $-0,608$ & 0,317 & $-0,535$ & 2,916 & 0,005 \\
\hline Profitabilitas & $-0,359$ & 0,336 & $-0,448$ & 3,069 & 0,007 \\
\hline Capital Intensity & 0,065 & 0,242 & 0,100 & 4,267 & 0,014 \\
\hline
\end{tabular}

Sumber: Data Penelitian, 2019

Berdasarkan Tabel 5, dapat diketahui bahwa Corporate Social Responsibility (CSR) memiliki nilai signifikansi sebesar 0,005 < 0,05 maka $\mathrm{H}_{1}$ diterima, hasil ini mempunyai arti yakni CSR berpengaruh terhadap penghindaran pajak. Pada Tabel 5, juga dapat diketahui bahwa profitabilitas memiliki nilai signifikansi sebesar 0,007 < 0,05. Hasil ini menyatakan bahwa profitabilitas berpengaruh terhadap penghindaran pajak. Dan juga pada Tabel 5, ini dapat diketahui bahwa capital intensity memiliki nilai signifikansi sebesar 0,014 $<0,05$. Hasil ini menyatakan bahwa capital intensity berpengaruh terhadap penghindaran pajak.

Hasil analisis penelitian ini mengungkapkan bahwa Corporate Social Responsibility (CSR) berpengaruh negatif terhadap penghindaran pajak. Hasil ini menunjukan bahwa semakin tinggi pengungkapan CSR, maka semakin tinggi tarif pajak efektif suatu perusahaan yang mengindikasikan rendahnya praktik penghindaran pajak yang dilakukan oleh perusahaan. Hasil ini sesuai dengan hipotesis yang menyatakan bahwa CSR berpengaruh negatif terhadap penghindaran pajak. Hal ini menandakan bahwa tinggi rendahnya pengungkapan 
CSR akan berdampak terhadap penghindaran pajak. Hasil penelitian ini sejalan dengan penelitan yang sebelumnya telah dilakukan oleh Dharma \& Noviari (2017), Park, (2017), dan Sari \& Adiwibowo (2017) yang menyatakan bahwa CSR memiliki pengaruh negatif terhadap penghindaran pajak.

Hasil penelitian ini mampu mengkonfirmasi teori stakeholder yang menyatakan bahwa perusahaan bukan merupakan entitas yang hanya bekerja untuk kepentingan perusahaan sendiri namun juga bermanfaat para stakeholder untuk menunjang kelangsungan usaha dengan pengungkapan CSR. Hasil penelitian ini juga mampu mengkonfirmasi pernyataan teori legitimasi yang menyatakan bahwa pengungkapan tanggung jawab sosial perusahaan perlu dilaporkan oleh perusahaan untuk mendapatkan legitimasi dari masyarakat. Pengungkapan CSR yang dilakukan oleh perusahaan dilakukan bukan untuk menghindari kewajiban pajak namun, untuk mengurangi kekhawatiran publik akan aktivitas yang dilakukan oleh perusahaan (Andhari \& Sukartha, 2017). Dengan mengurangi kekhawatiran publik, diharapkan perusahaan mendapat kepercayaan dari masyarakat maupun pihak eksternal lainnya.

Hasil penelitian mengungkapkan bahwa profitabilitas berpengaruh negatif terhadap penghindara pajak. Hasil ini menujukkan bahwa semakin tinggi tingkat profitabilitas yang dimiliki oleh perusahaan maka semakin besar tarif pajak efektif yang dimiliki oleh perusahaan sehingga praktik penghindaran pajak cenderung rendah. Hasil penelitian ini tidak sesuai dengan hipotesis yang menyatakan bahwa profitabilitas mempunyai pengaruh positif terhadap penghindaran pajak. Hal ini menandakan bahwa perusahaan yang memperoleh laba yang tinggi diasumsikan tidak melakukan praktik penghindaran pajak karena telah berhasil mengelola pendapatan dan pembayaran kewajiban perpajakannya dengan baik (Maharani \& Suardana, 2014). Hasil penelitian ini tidak sejalan dengan penelitian yang sebelumnya telah dilakukan oleh Putri \& Gunawan (2017). Namun, hasil penelitian ini didukung oleh Ambarukmini \& Diana (2017), Pradipta \& Supriyadi (2015), dan Saifudin \& Yunanda, (2016).

Menurut Kurniasih \& Sari (2013) hasil penelitian yang berpengaruh signifikan negatif karena tingkat profitabilitas perusahaan yang cenderung stabil. Peneliti Dyreng, et. al., (2017) mengemukakan bahwa perusahaan yang melakukan perencanaan pajak yang matang sehingga menghasilkan pajak yang optimal dan kecenderungan perusahaan dalam melakukan praktik penghindaran pajak menjadi menurun. Perusahaan yang beroperasi dengan efisiensi yang lebih tinggi akan mendapat tax subsidy berupa tarif pajak yang lebih rendah dibanding perusahaan yang beroperasi dengan efisiensi yang lebih rendah (Saifudin \& Yunanda, 2016).

Hasil penelitian tidak mampu mengkonfirmasi teori keagenan yang menyatakan bahwa agen atau manajemen perusahaan diberikan kekuasaan oleh stakeholder untuk mengelola laba perusahaan sehingga agen dapat melaporkan tingkat laba yang lebih rendah untuk menghindari kewajiban perpajakan. Hasil penelitan ini tidak mampu mengkonfirmasi teori akuntansi positif yakni hipotesis biaya politik yang menyatakan bahwa perusahaan yang besar dengan tingkat laba yang besar akan memilih metode akuntansi untuk mengurangi laba yang dilaporkan guna menghindari tuntutan lebih dari pihak eksternal perusahaan. 
Hasil penelitian ini mengungkapkan bahwa capital intensity berpengaruh positif terhadap penghindaran pajak Hasil ini menunjukkan bahwa semakin tinggi tingkat capital intensity yang dimiliki oleh perusahaan maka semakin rendah tarif pajak efektif yang dimiliki oleh perusahaan, sehingga cenderung terjadi praktik penghindaran pajak. Hasil penelitian ini sesuai dengan hipotesis yang menyatakan bahwa capital intensity berpengaruh positif terhadap penghindaran pajak. Semakin besar intensitas aset tetap yang dimiliki perusahaan maka semakin tinggi praktik penghindaran pajak perusahaan. Hasil penelitian ini sejalan dengan penelitian yang sebelumnya telah dilakukan oleh Darmadi \& Zulaikha (2013); Dharma \& Ardiana (2016); Noor, et. al., (2010). Peneliti Rodriguez \& Arias (2012) mengemukakan bahwa aset tetap yang dimiliki perusahaan memungkinkan perusahaan memotong pajak akibat dari penyusutan aset tetap perusahaan setiap tahunnya.

Capital intensity menggambarkan berapa besar kekayaan perusahaan yang diinvestasikan pada bentuk aset tetap. Aset tetap mencakup bangunan, pabrik, peralatan, mesin, property. Hampir semua aset tetap yang dimiliki oleh perusahaan mengalami penyusutan yang akan menjadi biaya penyusutan dalam laporan keuangan. Oleh karena itu, hal ini sangat berimplikasi terhadap laba perusahaan yang semakin menurun, sehingga pajak terutang perusahaan akan semakin menurun (Andhari \& Sukartha, 2017). Hal ini sejalan dengan penelitian yang dilakukan oleh Dharma \& Noviari (2017) yang mengemukakan bahwa perusahaan yang memiliki proporsi besar dalam aset tetap akan membayar pajak yang lebih rendah, karena perusahaan mendapat keuntungan dari penyusutan yang melekat pada aset tetap yang dapat mengurangi beban pajak. Penelitian ini mampu mengkonfirmasi teori akuntansi positif yakni hipotesis biaya politik. Perusahaan dapat memilih metode akuntansi yang digunakan untuk mengatur tingkat labanya guna menghindari tuntutan dari pihak eksternal yang mana dalam investasi perusahaan pada aset tetap.

\section{SIMPULAN}

Hasil penelitian ini memberikan hasil terkait olah data dan statistik mengenai penelitian dari pengaruh corporate social responsibility, profitabilitas dan capital intensity terhadap penghindaran pajak pada sektor perdagangan yang terdaftar di Bursa Efek Indonesia tahun 2013-2017. Hasil penelitian ini menunjukkan bahwa corporate social responsibility berpengaruh negatif terhadap penghindaran pajak yang diproksikan dengan ETR. Hasil ini mampu menjelaskan signifikasi teori stakeholder yang menyebutkan bahwa pengungkapan bahwa pengungkapan tanggung jawab sosial perusahaan merupakan salah satu bentuk dialog antara perusahaan dengan stakeholdernya. Peningkatan citra atau nilai perusahaan dapat diraih oleh perusahaan dengan meningkatkan pengungkapan CSR. Hasil dari penelitian ini juga mampu menjelaskan signifikasi teori legitimasi yang menyebutkan bahwa perusahaan harus dapat mengungkapkan berbagai aktifitas operasionalnya termasuk pengungkapan CSR sehingga perusahaan bisa mendapat penerimaan dari masyarakat atas bisnis yang dijalaninya. Dalam hal ini perusahaan telah mampu untuk melakukan tanggung jawab sosialnya dalam bentuk pembayaran kewajiban pajak sehingga praktik penghindaran pajak cenderung rendah. 
Hasil dari penelitian ini juga menemukan bahwa profitabilitas berpengaruh negatif terhadap penghindaran pajak. Hasil ini tidak mampu mengkonfirmasi teori keagenan yang menyatakan bahwa agen mendapat kewenangan yang diberikan oleh stakeholder guna meminimalisir laba yang diterima perusahaan sehingga perusahaan akan cenderung membayar pajak lebih rendah. Hasil dari penelitian ini tidak mempu mengkonfirmasi teori akuntansi positif yang menyatakan bahwa perusahaan dapat memilih metode akuntansi yang digunakan untuk mengurangi laba perusahaan.

Hasil dari penelitian ini mampu mengkonfirmasi teori akuntansi positif yang menyatakan bahwa perusahaan dengan tingkat laba yang tinggi memilih kebijakan akuntansi dan memanfaatkan kebijakan akuntansi yang ada untuk mengatur tingkat labanya, yang mana dalam investasi pada aset, perusahaan dapat memilih metode depresiasi yang dipandang dapat meminimalkan laba perusahaan sehingga perusahaan dapat meminimalkan pembayaran pajak.

Berdasarkan hasil penelitian yang didapatkan, diharapkan dapat memberikan kontribusi positif bagi semua pihak khususnya bagi perusahaan, pengguna laporan keuangan dan juga pemerintah. Bagi perusahaan penelitian ini diharapkan menjadi pertimbangan dalam pengambilan keputusan keuangan terutama dalam hal-hal yang menyangkut perpajakan. Bagi pengguna laporan keuangan yaitu investor, penelitian ini diharapkan menjadi pertimbangan bagi keputusan investasi dan bagi pemerintah, penelitian ini diharapkan dapat digunakan sebagai pertimbangan dalam meninjau kepatuhan wajib pajak perusahaan pertambangan sehingga penerimaan negara melalui pajak dapat lebih dioptimalkan lagi.

\section{REFERENSI}

Ambarukmini, K. T., \& Diana, N. (2017). Pengaruh Size, Leverage, Profitability, Capital Intensity Ratio dan Activity Ratio Terhadap Effective Tax Rate (ETR). E-Jurnal Ilmiah Riset Akuntansi, 06(17), 13-26.

Amidu, M., \& Coffie, W. (2019). Transfer Pricing, Earning Management, and Tax Avoidance of Firms in Ghana. Journal of Financial Crime, 34(1), 1-5.

Andhari, P. A. S., \& Sukartha, I. M. (2017). Pengaruh Pengungkapan Corporate Social Responsibility, Profitabilitas, Inventory Intensity, Capital Intensity, dan Leverage pada Agresivitas Pajak. E-Jurnal Akuntansi Universitas Udayana, 18(3), 2115-2142. https:/ / doi.org/ISSN: 2302-8556

Anouar, D. (2017). The Determinants of Tax Avoidance within Corporate Groups: Evidence from Moroccan Groups. International Journal of Economics, Finance and Management Sciences, 5(1), 57. https://doi.org/10.11648/j.ijefm.20170501.15

Atikah, N., Shafai, B., Bin Amran, A., \& Ganesan, Y. (2018). Earnings Management, Tax Avoidance and Corporate Social Responsibility: Malaysia Evidence. International Academic Journal of Accounting and Financial Management, 5(3), 41-56. Retrieved from www.iaiest.com

Bird, R., \& Davis-Nozemack, K. (2018). Tax Avoidance as a Sustainability Problem. Journal of Business Ethics, 151(4), 1009-1025. https://doi.org/10.1007/s10551-016-3162-2 
Cahyono, D. D., Andini, R., \& Raharjo, K. (2016). Pengaruh Komite Audit, Kepemilikan Institusional, Dewan Komisaris, Ukuran Perusahaan (Size), Leverage (DER) dan Profitabilitas (ROA) Terhadap Tindakan Penghindaran Pajak (Tax Avoidance) pada Perusahaan Perbankan yang Listing BEI Periode 2011-2013. Journal of Accounting, 2(2), 2016.

Darmadi, I. N. H., \& Zulaikha. (2013). Analisis Faktor yang Mempengaruhi Manajemen Pajak dengan Indikator Tarif Pajak Efektif (Studi Empiris Pada Perusahaan Manufaktur yang Terdaftar di Bursa Efek Indonesia Pada Tahun 2011-2012). Diponegoro Journal of Accounting, 2(4), 1-12.

Darmawan, I. G. H., \& Sukartha, I. M. (2014). Pengaruh Penerapan Corporate Governance, Leverage, Return on Assets, dan Ukuran Perusahaan pada penghindaran Pajak. E-Jurnal Akuntansi Universitas Udayana, 9(1), 143-161.

Dharma, I. M. S., \& Ardiana, P. A. (2016). Pengaruh Leverage, Intensitas Aset Tetap, Ukuran Perusahaan dan Koneksi Politik Terhadap Tax Avoidance. E-Journal Akuntansi Universitas Udayana, 15(1), 584-613.

Dharma, N. B. S., \& Noviari, N. (2017). Pengaruh Corporate Social Responsibility dan Capital Intensity Terhadap Tax Avoidance. E-Jurnal Akuntansi Universitas Udayana, 18(1), 529-556.

Dicky, M., \& Saputra, R. (2017). Pengaruh Profitabilitas, Leverage, dan Corporate Governance Terhadap Tax Avoidance. Jurnal Ilmu Dan Riset Akuntansi, 6(8), 1-19.

Dyreng, S. D., Hanlon, M., Maydew, E. L., \& Thornock, J. R. (2017). Changes in Corporate Effective Tax Rates Over The Past 25 Years. Journal of Financial Economics, 124(3), 441-463. https:// doi.org/10.1016/j.jfineco.2017.04.001

Ghozali, \& Chariri, A. (2007). Teori Akuntansi. Semarang: Badan Penerbit Universitas Diponegoro.

Goerke, L. (2018). Corporate Social Responsibility and Tax Avoidance. Journal of Public Economic Theory, 21(1).

Hazır, Ç. A. (2019). Determinants of Effective Tax Rates in Turkey. Journal of Research in Business, 1(4), 35-45. https:// doi.org/10.23892/jrb.2019453293

Henry, E., \& Sansing, R. (2018). Corporate Tax Avoidance: Data Truncation and Loss Firms. Review of Accounting Studies, Forthcoming, 23(1).

Hidayati, N., \& Fidiana. (2017). Pengaruh Corporate Social Responsibility dan Good Corporate Governance Terhadap Penghindaran Pajak. Jurnal Ilmu Dan Riset Akuntansi, 6(3), 1052-1070.

Kasim, F. M., \& Saad, N. (2019). Determinants of Corporate Tax Avoidance Strategies among Multinational Corporations in Malaysia. International Journal of Public Policy and Administration Research, 6(2), 74-81. https://doi.org/10.18488/journal.74.2019.62.74.81

Kim, J. H., \& Im, C. C. (2017). The Study on The Effect and Determinants of Smalland Medium-Sized Entities Conducting Tax Avoidance. Journal of Applied Business Research, 33(2), 375-390. https://doi.org/10.19030/jabr.v33i2.9911

Kurniasih, T., \& Sari, M. M. R. (2013). Pengaruh Retrun On Assets, Leverage, Corporate Governance, Ukuran Perusahaan, dan Kompensasi Rugi Fiskal pada Tax Avoidance. E-Journal Akutansi Universitas Udayana, 18(1), 58-66. https://doi.org/10.1016/j.giq.2005.05.002 
Lanis, R., \& Richardson, G. (2012). Corporate Social Responsibility and Tax Aggressiveness: An Empirical Analysis. Journal of Accounting and Public Policy, 31(1), 86-108. https://doi.org/10.1016/j.jaccpubpol.2011.10.006

Lin, K. Z., Cheng, S., \& Zhang, F. (2017). Corporate Social Responsibility, Institutional Environments, and Tax Avoidance: Evidence from a Subnational Comparison in China. International Journal of Accounting, 52(4), 303-318. https://doi.org/10.1016/j.intacc.2017.11.002

Maharani, I. G. A. C., \& Suardana, K. A. (2014). Pengaruh Corporate Governance, Profitabilitas Dan Karakteristik Eksekutif Pada Tax Avoidance Perusahaan Manufaktur. E-Jurnal Akuntansi Universitas Udayana, 2, 525-539. https://doi.org/10.20885/jaai.vol19.iss2.art1

McClure, R., Lanis, R., Wells, P., \& Govendir, B. (2018). The Impact of Dividend Imputation on Corporate Tax Avoidance: The Case of Shareholder Value. Journal of Corporate Finance (Vol. 48). Elsevier B.V. https://doi.org/10.1016/j.jcorpfin.2017.10.007

Merkusiwati, N., \& Damayanti, I. G. A. E. (2018). Faktor-Faktor yang Mempengaruhi Kemauan Wajib Pajak. Jurnal Aplikasi Bisnis, 13(1), 39-56.

Muzakki, M. R., \& Darsono. (2015). Pengaruh Corporate Social Responsibility Dan Capital Intensity Terhadap Penghindaran Pajak. Diponegoro Journal of Accounting, 4(3), 1-8.

Noor, R. M., Fadzillah, N. S. M., \& Mastuki, N. (2010). Corporate Tax Planning: A Study On Corporate Effective Tax Rates of Malaysian Listed Companies. International Journal of Trade, Economics and Finance, 1(2), 189-193. https:// doi.org/10.7763/IJTEF.2010.V1.34

Novitasari, S., Ratnawati, V., \& Silfi, A. (2017). Pengaruh Manajemen Laba, Corporate Governance, dan Intensitas Modal Terhadap Agresivitas Pajak Perusahaan. JOM Fekon, 4(1), 1901-1914.

Nugroho, A. A. (2011). Pengaruh Hubungan Politik dan Reformasi Perpajakan Terhadap Tarif Pajak Efektif pada Perusahaan yang Terdaftar di Bursa Efek Indonesia Tahun 2008-2009. Universitas Indonesia.

Park, S. (2017). Corporate social responsibility and tax avoidance: Evidence from Korean firms. Journal of Applied Business Research, 33(6), 1059-1068. https://doi.org/10.19030/jabr.v33i6.10045

Pradipta, D. H., \& Supriyadi. (2015). Pengaruh Corporate Social Responsibility (CSR), Profitabilitas, Leverage ,dan Komisaris Independen Terhadap Praktik Penghindaran Pajak. Jurnal Online Universitas Gadjah Mada.

Preuss, L. (2010). Tax avoidance and corporate social responsibility: You can't do both, or can you? Corporate Governance, 10(4), 365-374. https:/ / doi.org/10.1108/14720701011069605

Putra, I. G. L. N. D. C., \& Merkusiwati, N. K. L. A. (2016). Pengaruh Komisaris Independen, Leverage, Size dan Capital Intensity Ratio pada Tax Avoidance. E-Jurnal Akuntansi Universitas Udayana, 17.1, 690-714.

Putri, A. N., \& Gunawan. (2017). Pengaruh Size , Profitability , dan Liquidity terhadap Effective Tax Rates (ETR) Bank Devisa Periode 2010 - 2014. Jurnal Keuangan Dan Perbankan, 14(1), 18-28.

Putri, C. L., \& Lautania, M. F. (2016). Pengaruh Capital Intensity Ratio, Inventory Intensity Ratio, Ownership Structure dan Profitability Terhadap Effective 
Tax Rate (ETR) (Studi pada Perusahaan Manufaktur yang Terdaftar di Bursa Efek Indonesia Tahun 2011-2014). Jurnal Ilmiah Mahasiswa Ekonomi Akuntansi (JIMEKA), 1(1), 1. Retrieved from https:/ / media.neliti.com/media/publications/188375-ID-pengaruhcapital-intensity-ratio-invento.pdf

Rizki, M. Q. A., \& Fuadi, R. (2019). Pengaruh Karakter Eksekutif, Profitabilitas, Sales Growth Dan Corporate Social Responsbility Terhadap Tax Avoidance Pada Perusahaan Non-Keuangan Yang Terdaftar Di Bursa Efek Indonesia Tahun 2011-2015. Jurnal Ilmiah Mahasiswa Ekonomi Akuntansi, 4(3), 547-557. https://doi.org/10.24815/jimeka.v4i3.12592

Rodriguez, E. F., \& Arias, A. M. (2012). Do Business Characteristics Determine an Effective Tax Rate. The Chinese Economy, 45(6), 214-228. https://doi.org/10.2753/CES1097-1475450604

Saifudin, \& Yunanda, D. (2016). Determinasi Return On Asset, Leverage, UKuran Perusahaan, Kompensasi Rugi Fiskal dan Kepemilikan Institusi Terhadap Penghindaran Pajak ( Studi Empiris Pada Perusahaan Manufaktur yang Terdaftar di BEI Tahun 2011-2014). Jurnal Penelitian Ilmu Ekonomi Wiga, 6(2), 131-143.

Saputra, M. F., Rifa, D., \& Rahmawati, N. (2015). Pengaruh Corporate Governance, Profitabilitas dan Karakter Eksekutif Terhadap Tax Avoidance. Jurnal $\begin{array}{lllll}\text { Akuntansi } \mathcal{E} \quad \text { Auditing Indonesia, } & 19(1),\end{array}$ https://doi.org/10.20885/jaai.vol19.iss1.art1

Sari, L. L. P., \& Adiwibowo, A. S. (2017). Pengaruh Corporate Social Responsibility Terhadap Penghindaran Pajak. Diponegoro Journal of Accounting, 6(4), 1-13.

Sikka, P. (2010). Smoke and mirrors: Corporate social responsibility and tax avoidance. Accounting Forum, 34(3-4), 153-168. https://doi.org/10.1016/j.accfor.2010.05.002

Zeng, T. (2018). Relationship Between Corporate Social Responsibility and Tax Avoidance: International Evidence. Social Responsibility Journal, 15(2), 244257. https:// doi.org/10.1108/SRJ-03-2018-0056

Zhu, N., Mbroh, N., \& Bonsu, M. O. (2019). Corporate Tax Avoidance and Firm Profitability. European Scientiific Journal, 15(7), 61-70. https://doi.org/10.19044/esj.2019.v15n7p61 